\title{
THE DEVELOPMENT OF REFUGEE LAW CLINICS IN GERMANY IN
}

\section{VIEW OF THE REFUGEE CRISIS IN EUROPE}

Jan-Gero Alexander Hannemann, University of Goettingen

Georg Dietlein, University of Cologne

\section{INTRODUCTION}

Coming to an unknown country, seeking for refuge, having nobody anymore, because of the family murdered by a criminal regime, not being able to speak the language of the country, having no idea of the legal system - this scenario can put refugees in very difficult circumstances, especially if the refugees need legal advice concerning their situation. There is not only the pressure of getting along with the horrific experiences the refugee went through but sometimes even legal problems that have to be solved, sometimes problems that may decide whether a person can stay in the country or has to leave it.

And most of the time small issues, like how to deal with certain formalities or what steps to undertake next, are in question. This is where law clinics, especially the specialized refugee law clinics, might help. 


\section{DEVELOPMENT OF LAW CLINICS IN GERMANY}

Law clinics and clinical legal education are a new and fast developing field within the German jurisdiction. ${ }^{1}$ Until 2008 law clinics were not allowed under a German law (Rechtsberatungsgesetz) which partly goes back to the time of national socialism in Germany that aimed at pushing Jewish lawyers out of the legal advisory market. ${ }^{2}$ In order to give legal advice (even free of charge or among relatives) you needed a state permission, which is available only to the members of the bar. The law did not provide any exception for free legal services (including those of law clinics), legal advice within the family or at least giving simple legal advice on specific topics which can be handled by non-attorneys (like the LLLT-model in Washington allows ${ }^{3}$ ). This led to the

${ }^{1}$ See J.-G. A. Hannemann / G. Dietlein, Studentische Rechtsberatung in Deutschland, JURA Juristische Ausbildung, Vol. 39 (2017) p. 449 - 460; see also J.-G. A. Hannemann / J. Lampe, Clinical Legal Education - Observing, Comparing and Analyzing the Differences in Germany and China for Each Other's Respective Advantages, 2 AsIAN J. LEgAL EDUCATION 157 - 169 (2015); U. Stege, Le développement du mouvement clinique en Europe, in: Xavier Aurey (ed.), LES CLINIQUES JURIDIQUES 49 - 60 (PUC Caen 2015).

${ }^{2}$ Original version: Gesetz zur Verhütung von Mißbräuchen auf dem Gebiete der Rechtsberatung (Law on the prevention of abuses in the field of legal advice, 13th December 1935), in: Reichsgesetzblatt 1935 I p. 1478 seq.; later called „,Rechtsberatungsgesetz“ (Act on legal services, since 1962); see Weber, Die Ordnung der Rechtsberatung in Deutschland nach 1945 (Tübingen 2010); Simone Rücker, Rechtsberatung. Das Rechtsberatungswesen von 1919-1945 und die Entstehung des Rechtsberatungsmissbrauchsgesetzes von 1935 (Tübingen 2007).

${ }^{3}$ A "Limited License Legal Technician" is not a fully trained lawyer, but a trained and licensed person "to render limited legal assistance or advice in approved practice areas of law" (Washington's Admission to Practice Rules, Rule 28). The aim was to give (affordable) legal advice to those who are unable to afford the services of an attorney. At the moment (since their introduction in Washington in 2012), Legal Technicians are authorized only to advise clients in family law cases (divorce, custody). The Washington State Bar Association compares them with a nurse (which fits well into the image of a legal "clinic"): "Think of them like nurse practitioners, who can treat patients and prescribe medication like a doctor- well-trained, qualified and competent professionals who can provide you with the help you need" (see www.wsba.org/Licensing-and-Lawyer-Conduct/Limited-Licenses/LegalTechnicians). 
grotesque situation that a fully trained law graduate in Germany who decided not to work as an attorney but a judge could not even give free legal advice to his son. In 1998 Helmut Kramer, Judge at the Higher Regional Court of Braunschweig, started an initiative to have the Rechtsberatungsgesetz declared unconstitutional: $\mathrm{He}$ - as a judge - gave free legal advice, indicated himself to the authorities, was punished with a fine of 600 Deutsche Mark (350 \$) and brought this case to the Federal Constitutional Court of Germany, which in 2004 finally gave him right. ${ }^{4}$

In 2007 the German law of legal counselling was fundamentally reformed. Since 2008 everyone is allowed to provide legal advice free of charge under certain conditions. $\S$ 6 of the German Rechtsdienstleistungsgesetz says: "Legal services which are not connected to paid activity (free legal services) are permitted. Any person providing free legal service outside family, neighbourhood or similar close personal relations shall ensure that this legal service is provided by a person authorized to give such legal services, by a person with a qualification to judge or under the guidance (Anleitung ${ }^{5}$ ) of such a person. Guidance requires briefing and training as well as participation in the provision of the legal service depending on the scope and content of the legal services to be provided, as far as necessary in the individual case." With this reform, the legislator explicitly wanted to allow charitable involvement

\footnotetext{
${ }^{4}$ Federal Constitutional Court OF Germany (Bundesverfassungsgericht), Decision of 29th July 2004 (1 BvR 737/00), in: Neue Juristische Wochenschrift 2004, p. 2662 (also see: http://www.bundesverfassungsgericht.de/SharedDocs/Entscheidungen/DE/2004/07/rk20040729_1bvr0 73700.html).

${ }^{5}$ The German word "Anleitung" is a key word at this point, since it is crucial for the legal frame of legal clinics. "Anleitung" basically means to guide someone. It is important to note that "Anleitung" (guidance) is not such a strong word like direction, supervision, instruction or monitoring.
} 
in the field of legal advice which previously (at least for non-attorneys) was prohibited $^{6}$.

Due to this change, law clinics became allowed in Germany for the very first time. Actually, this legal development was prepared by the jurisdiction of the German Constitutional Court (Bundesverfassungsgericht) which stated that free legal advice (by a legally trained person) cannot be prohibited in general. ${ }^{7}$ There used to be law clinics/first experiments even before 2008, but officially their interactions were illegal. Since 2008, more and more law clinics were opened. Since 2011 law clinics spread all over the country. ${ }^{8}$ Suddenly law clinics became more and more accepted within society, university and academic curricula. The first student law clinics have been founded - either on the initiative of universities or by students themselves. Meanwhile almost every German law faculty has at least one law clinic. Until 2016 there developed more than 132 law clinics, until 2018 even 152 - of which one can consider approximately 76 to be stable and long-lasting. In 2012 a few law clinics formed the German law clinic umbrella organization BSRB (Bund Studentischer Rechtsberater) ${ }^{9}$

\footnotetext{
6 See DEUTSCHER BundeSTAG (German Parliament), Bundestags-Drucksache (parliamentary materials) no. 16/3655, p. 39 (http://dip21.bundestag.de/dip21/btd/16/036/1603655.pdf).

${ }^{7}$ Federal CONSTITUTIONAL COURT OF GERMANy (Bundesverfassungsgericht), Decision of 16th February 2006 (2 BvR 1087/04 and 2 BvR 951/04), in: Neue Juristische Wochenschrift 2006, p. 1502 (also see:

www.bundesverfassungsgericht.de/SharedDocs/Entscheidungen/DE/2006/02/rk20060216_2bvr095104. html).

${ }^{8}$ J.-G. A. Hannemann, GJLE [German Journal of Legal Education] 2016, p. 199 seq. (b-s-r-b.de/wpcontent/uploads/2016/06/GJLE_vol3_2016.pdf).

9 J.-G. A. Hannemann / G. Dietlein, STUDENTISCHE ReChtSBERATUNG Und CLINICAL LEGAL EDUCATION IN DEUTSCHLAND, p. 31 seq. (Springer Berlin 2016); J.-G. A. Hannemann / P. Mertes, GJLE 2014, p. 165; J.-G. A. Hannemann / J. Lampe, Justament 09/2012, 16; J.-G. A. Hannemann / G. Dietlein, Studentische Rechtsberatung, AD LEGENDUM, Vol. 11 (2014), p. 79.
} 
which also publishes a journal about clinical legal education approaches in Germany $($ German Journal of Legal Education $=G J L E) .{ }^{10}$ Nowadays there are even first court decisions concerning clinical legal education. ${ }^{11}$

Law clinics in Germany usually have two interests: on the one hand, there are students who want to practice law (which they are taught at university), who want to gather first experiences and understand what it means to be a lawyer, on the other hand, law clinics always have a social and charitable component. Law clinics also want to give access to justice. ${ }^{12}$ This is why they are not only helpful in an academic system, but also in the legal system.

Law clinics are - like "legal technicians" - a good way to get an affordable (which means free) and limited legal advice. ${ }^{13}$ These two aspects, the social and the academic one correlate with each other. The client is a concrete person with human dignity and a real problem that urges to be solved. This is also the reason why students prefer to work on real cases from everyday life than on pure academic cases. At least this is the experience of everyone who became a member of a law clinic. But even more important is the fact that students - in the very theoretical and fictional case-based legal education in Germany - mostly learn more by working on real cases than on theoretical. The life

\footnotetext{
${ }^{10}$ ISSN: 2509-8667.

${ }^{11}$ G. Dietlein / J.-G. A. Hannemann, NJW [Neue Juristische Wochenschrift] 2015, p. 1123 seq.

12 See Frank S. Bloch, Access to Justice and the Global Clinical Movement, 28 WASH. U. J. L. \& POL'Y 111 (2008); Stephen Wizner / Jane Aiken, Teaching and Doing: The Role of Law School Clinics in Enhancing Access to Justice, 73 FORDHAM L. REV. 997 (2004).

${ }^{13}$ Cfr. footnote 3 .
} 
is the best teacher. And real cases (in which something is at stake) are the best appetizers to deal with the theoretical basics.

Most of the cases law clinics receive are cases in the field of consumer law (purchases, rent, employment law etc.). ${ }^{14}$ There are even a few approaches to deal with criminal law, which is still quite difficult in Germany to do as a student. ${ }^{15}$ This is related to the fact that in a criminal case only an attorney can obtain access to the files of the public prosecutor and may appear in court. ${ }^{16}$ Due to the importance of a penal judgement for the sentenced person, this seems to be justified. There are also various specialized law clinics which deal with internet law or start-ups. ${ }^{17}$ Another special type of law clinics are refugee law clinics which have acquired a high significance due to the refugee crisis in Europe. ${ }^{18}$ In 2016 about 37 specialized refugee law clinics offer legal advice especially to refugees. ${ }^{19}$

The authors want to point out the importance of refugee law clinics within the German system, the legal framework of student legal counselling in Germany, the background of the refugee law clinics as well as their benefits to society as a whole.

\footnotetext{
${ }^{14}$ J.-G. A. Hannemann, First statistical evaluation of the development of law clinics in Germany, GJLE 2015, p. 145 seq.

${ }^{15}$ The law clinic from the "Freie Universität Berlin" is for example offering legal advice in the field of criminal law (see http://www.jura.fuberlin.de/fachbereich/einrichtungen/strafrecht/lehrende/momsenc/FU-Law-Clinic/index.html [01.09.2017]).

${ }^{16}$ J.-G. A. Hannemann / G. Dietlein, Studentische ReChtsberatung UnD ClinicAl LEGAL EDUCATION IN DEUTSCHLAND, p. 25 seq. (Springer Berlin 2016).

${ }_{17}$ J.-G. A. Hannemann, Overview of existing law clinics in Germany (Übersicht bestehender Legal Clinics in Deutschland), GJLE 2016, p. 199 seq.

${ }_{18}$ Cfr. GJLE 2017, p. 34.

${ }^{19}$ J.-G. A. Hannemann / G. Dietlein, StUdentisChe ReCHTSBERATUNG UND CLINICAL LEGAL EDUCATION IN DeUTSCHLAND, p. 31 seq. (Springer Berlin 2016).
} 


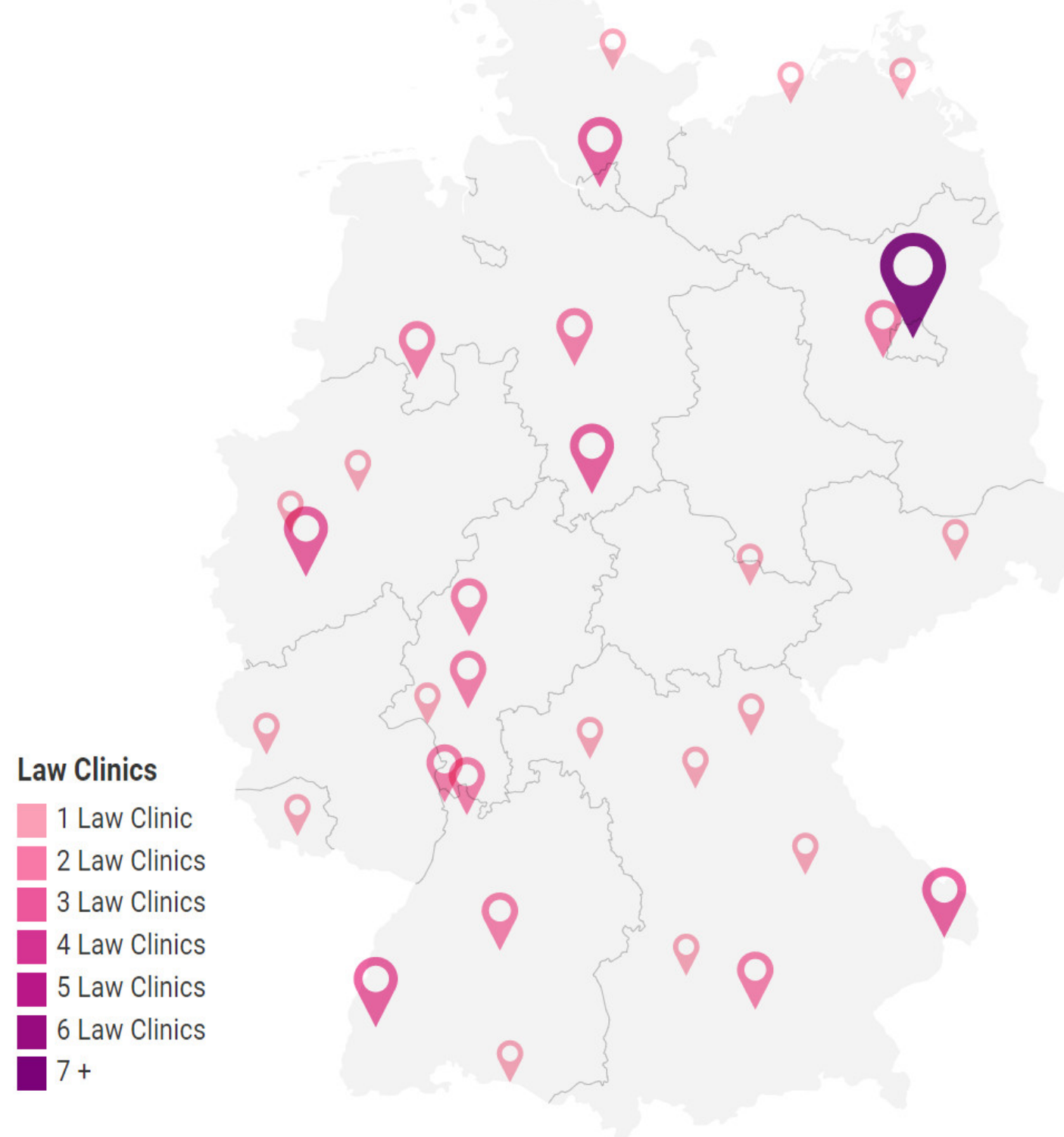

Map: The map shows the different refugee law clinic locations in Germany. The size of the arrow indicates the number of law clinics at the specific place. Surprisingly there is no city where two refugee law clinics are working independently from each other. Every city has just one refugee law clinic, but sometimes several civil law / general law clinics (not specialised on refugee law). The map also shows that not in every city a refugee law clinics exists and that 
there are much more civil / general law clinics. This map does not show all civil / general law clinics in Germany.

\section{THE REFUGEE CRISIS IN GERMANY}

Germany is an immigration country. In 2014 every fifth person (which is about 16 million people) has had at least one migration background within the family (which means that at least one member of the family had immigrated to Germany since 1949 or had ancestors who immigrated since 1949). ${ }^{20} 56 \%$ of these people hold the the German citizenship. $44 \%$ of all people who immigrated since 2011 have an academic degree, whereas in the German society "only" $24 \%$ have achieved graduation. One could add that $28 \%$ of immigrants do not have any professional qualification and $8 \%$ no school graduation (often due to personal circumstances in the situation of persecution).

While in former times foreigners often came to Germany as immigrant workers (in order to work there for several years and later leave the country again which often did not happen), the massive immigration to Germany in the years 2014 - 2016 was a refugee topic which has its roots in war, expulsion, political and religious persecution and also in social poverty. ${ }^{21}$ The extraordinary number of refugees and asylum seekers from Syria, Iraq, Afghanistan, Albania and many other states in 2014 to 2016 led

\footnotetext{
${ }^{20}$ Federal Statistical Office (Germany), Statistical YeARBOOK 2014 - GERMANY AND INTERNATIONAL, p. 42 (Statistisches Bundesamt, Statistisches Jahrbuch 2014 - Deutschland und Internationales).

${ }^{21}$ See Patrick Kingsley, The New Odyssey: The Story OF Europe's RefugEe Crisis (London 2016). More data see: eurostat, Asylum and first time asylum applicants by citizenship, age and sex Annual aggregated data (rounded), http://ec.europa.eu/eurostat/en/web/products-datasets//MIGR_ASYAPPCTZA
} 
Germany and whole Europe into a pan-European refugee crisis. In the core time (October 2015 - September 2016) more than 50.000 asylum applications were monthly filed with the Federal Office for Migration and Refugees (Bundesamt für Migration und Flüchtlinge $=\mathrm{BAMF}) .{ }^{22}$ Overall, there were more than one million asylum applications in 2014 to 2016 (2014: 200,000 / 2015: 475,000 / 2016: 745,000). ${ }^{23}$ About 300.000 asylum procedures are still pending in 2017. Every month more than 25,000 hearings are held and more than 70,000 decisions on applications for asylum are made, of which over 40 $\%$ are positive. ${ }^{24}$ This did not only lead to an excessive overload of the BAMF, but of all parties involved in refugee management (municipalities, churches, private organisations) since the refugees were already in Germany when applying for asylum. The discussion about the admission procedures for refugees and foreigners in Germany was heated by the fear of terror and crime and polarized the entire country. One should note the particularly important role of the Chancellor of Germany Angela Merkel who stand up for the opening of Europe for refugees against strong political resistance. ${ }^{25}$ Matthias M. Mayer (Bertelsmann Foundation Germany) remarks correctly: "Merkel is clearly the face of Germany's refugee policy. Before the summer of 2015,

\footnotetext{
${ }^{22}$ Federal Office for Migration and Refugees (Germany), Asylum statistics 2 / 2017 (www.bamf.de/SharedDocs/Anlagen/DE/Downloads/Infothek/Statistik/Asyl/201702-statistik-anlageasyl-geschaeftsbericht.pdf).

${ }^{23}$ Federal Office for Migration and Refugees (Germany), Recent statistics 2 / 2017, p. 3 (www.bamf.de/SharedDocs/Anlagen/DE/Downloads/Infothek/Statistik/Asyl/aktuelle-zahlen-zu-asylfebruar-2017.pdf).

${ }^{24}$ Federal Office for Migration and Refugees (Germany), Asylum statistics April 2017, p. 10 (www.bamf.de/SharedDocs/Anlagen/DE/Downloads/Infothek/Statistik/Asyl/aktuelle-zahlen-zu-asylapril-2017.pdf?_blob=publicationFile).

${ }_{25}$ See Joyce Marie Mushaben, Angela Merkel's Leadership in the Refugee Crisis, 116 CURRENT HISTORY (2017), Issue 788, p. $95-100$.
} 
Merkel's style of politics was characterized by pragmatism and incremental steps, rather than following a sweeping political vision. Now, in a departure from her usual style, Merkel has made Germany's open asylum policy her personal political project-despite strong resistance from many quarters." ${ }^{26}$

Germany is one of the richest countries in Europe and has a tremendous responsibility (not only of historical nature). Many citizens are concerned about the refugees and their life circumstances. But asylum law can also be abused. One has to differentiate between a refugee (someone who has to leave his country forcedly because he is persecuted or no longer safe) and general migration, especially the so called "economic refugees" (those who have a future in their country, but hope for a better life in another country). With regard to the limited availability of resources and capacities in every country, this distinction is a question of justice - as some refugees are really worried about their life, while others are only concerned about the quality of their life. This is why immigration needs regulation. In the area of (ordered) migration it is legitimate to look at criteria like language skills, school degrees, chances on the labour market etc. With regard to refugees these criteria are absolutely inappropriate. The aim is to protect human beings from persecution, regardless of whether the host country benefits from it.

\footnotetext{
${ }^{26}$ Matthias M. Mayer, Germany's Response to the Refugee Situation: Remarkable Leadership or Fait Accompli?, p. 6, in: Bertelsmann Foundation, Newpolitik, May 2016, available at www.bfna.org/sites/default/files/publications/Germanys_Response_to_the_Refugee_Situation_Mayer. pdf
} 
Refugees are regularly confronted with a variety of complex legal issues which they cannot handle with - not only because of the language. ${ }^{27}$ In 2013 approximately 51.2 million people were fleeing worldwide, of whom about 187,600 were accepted as refugees in Germany. ${ }^{28}$ In addition, 109,580 initial asylum applications were submitted..$^{29}$ From 173,072 in $2014^{30}$ this number increased to 441,899 in $2015^{31}$ in

\section{Germany.}

The refugee crisis in Germany is also accompanied by an overload of courts and public administration. For most judges and public officials the flood of asylum applications came surprisingly. Resources are missing to answer all asylum requests in reasonable time. The refugee crisis led to a human resource crisis at some regional courts and regional administrations. This leads to the unacceptable situation, that in a large number of asylum procedures and court proceedings nothing happens for a long time. The average process time at some courts is already nine months, even if asylum seekers need fast solutions. ${ }^{32}$

Especially since 2016 the administrative courts in Germany (Verwaltungsgerichte) have been overloaded with proceedings. Every fourth asylum procedure goes to

\footnotetext{
27 Refugee Law Clinic Munich, Annual Report, p. 11

(http://www.lawclinicmunich.de/images/LawClinicMunich_Jahresbericht_1415.pdf).

${ }_{28}$ UNHCR Global Trends 2013, p. 13 (www.unhcr.de/service/zahlen-und-statistiken.html [01.09.2017]).

${ }^{29}$ Federal Statistical Office (Germany), STATISTICAL YEARBOOK 2014 - GERMANY AND INTERNATIONAL, p. 42.

${ }^{30}$ Ibid., p. 41.

${ }^{31}$ Ibid., p. 42.

32 See www.tagesspiegel.de/berlin/fluechtlinge-in-berlin-zahl-der-asylverfahren-vor-demverwaltungsgericht-steigt-stark/14671732.html.
} 
court. ${ }^{33}$ In some administrative courts, asylum procedures account for two-thirds of all administrative proceedings (e.g Münster ${ }^{34}$, Gelsenkirchen ${ }^{35}$ ). In many courts the asylum procedures have tripled from 2015 to 2016 (e.g. Saarland ${ }^{36}$ ) or even quadrupled (like in Berlin: over 9.000 asylum complains in $2016^{37}, 13.000$ procedures pending ${ }^{38}$ ). By the way, a large proportion of all complaining asylum seekers are Syrians who fight against the fact that they were only granted subsidiary protection, which does not entitle their families to come to Germany for family reunion. In most of these proceedings, the administrative courts grant the applicants from Syria the full asylum protection which is given to all refugees in the situation of political persecution. On the other hand, it has to be noted, that other refugees (mostly from Albania, Serbia, Macedonia, Kosovo, Bosnia-Hercegovina) bring an action to court, even though they know they have no chance of being recognized as asylum seekers. ${ }^{39}$ Asylum law and court processes, which give more time until to have to leave the country or being deported, can also be abused.

\footnotetext{
${ }^{33}$ See www.zeit.de/politik/deutschland/2017-07/asylverfahren-verwaltungsgericht-richterueberlastung-flluechtling.

${ }^{34}$ See www.wn.de/Muenster/2651382-4571-Faelle-beim-Verwaltungsgericht-Asylverfahren-sorgenfuer-Klagewelle.

${ }^{35}$ See www.waz.de/staedte/gelsenkirchen/die-zahl-der-asylverfahren-nimmt-rasant-zuid209297363.html.

${ }^{36}$ See www.focus.de/regional/trier/migration-saar-verwaltungsgericht-asylverfahren-zahlverdreifacht_id_6451391.html.

${ }^{37}$ www.moz.de/artikel-ansicht/dg/0/1/1540175.

${ }^{38}$ www.rbb24.de/politik/beitrag/2017/08/verwaltungsgericht-berlin-kritik-bamf-asylverfahren.html.

${ }^{39}$ www.faz.net/aktuell/politik/inland/asylklagen-an-verwaltungsgerichten-auf-hoechststand13755084.html.
} 


\section{THE DEVELOPMENT OF REFUGEE LAW CLINICS IN GERMANY}

Also lawyers recognized that there is a lack in understanding the refugee law throughout Germany. This is why they established specialization in the field of refugee law / migration law for lawyers (§ 14p Fachanwaltsordnung). ${ }^{40}$

This development underlined the importance of refugee clinics. More and more citizens became interested in this field and started to work for refugee law clinics, even people with no law background at all. ${ }^{41}$

\section{THE LEGAL FRAMEWORK OF REFUGEE LAW CLINICS}

A great chance for the constitutional state, but also for the refugees themselves are the refugee law clinics which record a massive spread all over the country since 2013. The law of asylum in Germany is relatively complex. Since it is normally not component of the law curriculum at university, refugee law clinics organize their own courses in foreigners' law, mostly in cooperation with attorneys who practice in this topic. These attorneys are often also willed to accompany and supervise the work of the refugee law clinic (which is necessary according to German law). The Act on Legal services (RDG 2007) allows law students (and actually everyone) to advise clients free of charge as long as they are guided by a person who is authorized to provide legal services or has the qualification as a judge which is to have passed the second state examination

\footnotetext{
${ }^{40}$ Kai von Lewinski, Law Clinics in der Fachanwaltsausbildung - Knappen als Königsmacher?, GJLE 2016, p. 53 seq.

${ }^{41}$ Boris Paal, GJLE 2016, p. 2.
} 
(e.g. every educated lawyer, judge, attorney at law, notary, public prosecutor). The legal question is how far such guidance by a lawyer has to be made. ${ }^{42}$ This question has implications for the organization of the legal clinic, because if "guidance" really means strict supervision, the law students cannot really work independently on their cases and for the supervisor going through every little detail of the case (again) would not be efficient, especially when dealing with easy and standard cases.

On the other hand, a guidance that is not strict enough can lead to advisory errors which have to be avoided in the interest of the client who cannot assess the quality of legal advice.

\section{The education that is necessary to work in a refugee law clinic}

Refugee law is in Germany not part of the standard academic curriculum for law students. ${ }^{43}$ Before students are allowed to work in a refugee law clinic, they have to go through one or two semesters of preparation courses which usually contain at least one lecture on refugee law as well as a weekly tutorial where students discuss cases with their supervisors / cooperating attorneys / professors. ${ }^{44}$ Some refugee law clinics provide "fast track" education programs, e.g. seven intensive weeks with a total workload of 42 hours. ${ }^{45}$ Many of them want their students to undertake an internship (with an attorney) before they are advising someone. ${ }^{46}$

\footnotetext{
${ }^{42}$ See fn. 4.

${ }^{43}$ Schaich, GJLE 2016, p. 156 seq.

${ }_{44}$ Born, GJLE 2015, p. 103; Thomson, GJLE 2015, p. 108; Uzuner, GJLE 2015, p. 113.

${ }^{45}$ Thomson, GJLE 2015, p. 110.

${ }^{46}$ Uzuner, GJLE 2015, p. 115.
} 
A few law clinics also established cooperation with other refugee helping institutions where the students can already test their knowledge under lawyer supervision. ${ }^{47}$

A few refugee law clinics are also educating people to be legal advisors who are not law students. ${ }^{48}$

Since these law clinics are organised by students they have a statute and organise the Refugee law clinic in the legal form of a registered association ("eingetragener Verein") which is a public registered, non-profit organisation and usually works independently from the prospective university. ${ }^{49}$ This is to be considered the most common legal form for German law clinics in general ${ }^{50}$ even though there is a strong trend for law clinics to enter a cooperation with the university. ${ }^{51}$

\section{Why is working in a refugee law clinic an advantage to the students?}

The refugee crisis hit Europe hard. The media are reporting about this topic on a daily base. Especially young people are interested in helping to improve the situation or refugees and to set an impact. ${ }^{52}$ This is mostly the first motive to work in a refugee law clinic.

In a few refugee law clinics it is also possible to get a certificate which can be recognized in the academic curriculum at law school / university as a law course or a

\footnotetext{
47 Born, GJLE 2015, p. 103.

48 Born, GJLE p. 2015, 104; Uzuner, GJLE 2015, p. 114.

49 Thomson, GJLE 2015, p. 109.

${ }^{50}$ Hannemann, GJLE 2015, p. 138 seq.

${ }^{51}$ Hannemann, GJLE 2015, p. 138.

52 Uzuner, GJLE 2015, p. 113.
} 
legal internship..$^{53}$ Such an internship is particularly interesting for German law students, as an internship / practical training of three month is required for the first state exam in law.

The confrontation with asylum law (which is not part of the standard academic curriculum in law school) expands the horizon of students and can give them new motivation for their studies, since they recognize that legal issues can play an existential role in real life. But this is only a side effect of a refugee law clinic. ${ }^{54}$ The main focus is on the concerns of the refugees, even if they are less interesting for law students or concern non-legal topics. However, this also leads to a small disadvantage of the refugee law clinics: the relevance of asylum law in the state exam is rather low (compared to consumer law or general civil law).

\section{What cases are refugee law clinics working on?}

Usually the refugees have concrete questions concerning the whole process of seeking asylum in Germany. ${ }^{55}$ After solving all the questions, they are accompanied through the process of seeking asylum by usually at least two members of the refugee law clinic who are supervised by a lawyer (mostly an attorney-at-law) who is specialised in asylum law. ${ }^{56}$

\footnotetext{
53 Thomson, GJLE 2015, p. 111.

${ }^{54}$ Born, GJLE 2015, p. 102.

${ }^{55}$ Born, GJLE 2015, p. 103.

${ }^{56}$ Born, GJLE 2015, p. 103.
} 
Refugee law clinics are helping people to cope with legal questions concerning asylum law. But it is not only the refugee law that is put into focus but sometimes even simple non-legal problems that occur, e.g. dealing with certain administrative matters that can easily become quite difficult. In Germany, asylum law is a fundamental right for politically persecuted, protected by the constitution (Art. 16a Grundgesetz ${ }^{57}$ ). But only few people actually can rely on this fundamental right which is granted under certain conditions. In addition, refugees can derive rights from international and European regulations (1951 Refugee Convention, EU Dublin regulation, EU regulations 2011/95/EU, 2013/32/EU, 2013/33/EU). All national regulations concerning refugees are bundled in the German Asylgesetz (national asylum act 1992 ${ }^{58}$ ) which is supplemented by the Asylbewerberleistungsgesetz (act concerning aid / services for asylum seekers 199359). Important are also the regulations in the Aufenthaltsgesetz (act about the residence, employment and integration of foreigners in the federal territory $2004^{60}$ ). At the end of a asylum procedure, there is a decision which either allows the asylum seeker to remain in the country or not. There are different statuses that entitle a person to stay in Germany for a certain period of time (status as a refugee, subsidiary protection, ban on deportation, recognition as asylum seeker with fundamental asylum right). And if the asylum seeker receives a negative decision concerning his

\footnotetext{
${ }^{57}$ The "Grundgesetz" (Fundamental Law) is the Constitution of the Federal Republic of Germany, cfr. https://www.gesetze-im-internet.de/gg/art_16a.html.

${ }_{58}$ Recently published in: Bundesgesetzblatt I 2008, p. 1798 seq.

${ }^{59}$ Original version: Bundesgesetzblatt I 1993, p. 1074 seq.

${ }^{60}$ Original version: Bundesgesetzblatt I 2004, p. 1950 seq.
} 
request for asylum there is always the possibility to go to court. The court might alter the administrative decision.

\section{Asylum questionnaire}

Quite often refugees need help with completing a typical asylum questionnaire. Even though these questionnaires exist in several languages it is sometimes difficult to understand the legal terms which are used in such forms. Especially if the asylum seeker has no specific education or never had to deal with administrative stuff. Sometimes this can be confusing and difficult coming from a different jurisdiction. This is also a field which law clinicians will help in.

\section{The hearing}

Also refugee law clinics try to help their clients to prepare for the hearing ("Anhörung"). ${ }^{61}$ This is a very important step in the asylum procedure where the refugee will be interviewed by German administrative officials. Within this hearing there are several experts estimating whether the refugee should receive the so-called asylum title or not. There are translators and even people from the particular region the refugee is referring to be his home region to estimate if the refugees is telling the truth. The hearing is of great importance since here will be made a decision whether the asylum seeker will be considered to be a refugee who is seeking for asylum because

${ }^{61}$ Hilb, GJLE 2014, p. 126 seq. 
he is threatened in his country with death, bodily harm or discrimination. Many asylum seekers only wish to improve their life circumstances. These are so called economic asylum seekers. These people have to go back to their countries because the places are reserved for those who otherwise will not be able to survive because of war and other disturbing circumstances. Therefore, the translators are even investigating whether the dialect the person is speaking is authentic. Moreover, the story how the refugee came to Germany has to make sense. In case of doubt there are always an examination as well as several tests to find out if the asylum seeker belongs to the group of officially recognized refugees. The committee will even investigate on the language and especially the accent the refugee is speaking. Experts know the habits in the particular region in detail. On that base one can find out if the truth was told or not.

Based on the decision from this committee it might happen that the asylum seekers will be send back to his country. In this case the government will pay for his flight back and provide him sufficient money to start a new life back home. For asylum seekers who do already know that they will not be considered to be refugees there is the option to declare themselves to go back to their country of origin and then to receive an extra amount of money as motivation to go back home.

If the person is officially recognized to be a refugee in Germany he will receive a monthly payment as well as place to live for free.

But what if something went wrong within the procedure of the hearing and due to misunderstandings or other circumstances the asylum seeker's request for asylum will 
be denied? In this case one has to go as quick as possible to the courts before the asylum seeker will be send back to maybe even a country he does not belong to.

\section{Help on non-legal problems}

It is not easy to get along in a new country, when someone comes from a different jurisdiction. Sometimes refugee law clinics have to help on non-legal problems. Either in other fields of law (e.g. labour law or family law) or with general life questions like how to visit the doctor or receiving medicine. Of course, there are even more random questions that might come up.

Refugee law clinics also help in these fields.

\section{HOW DO REFUGEE LAW CLINICS WORK IN GERMANY?}

\section{Proper training of students before legally advising refugees}

First of all, students who are involved in refugee law clinics can be divided into two groups. First group includes translators who help to translate documents, letters as well as conversations. These students do not have to be law students. In fact, it is not even necessary that they are students at university as long as they are able to help in translating, but most of translators in refugee law clinics are law students. ${ }^{62}$

The other group are students who want to give legal advice to refugees. These students - who already have studied law - nevertheless have to go through a special training

${ }^{62}$ Hannemann, GJLE 2015, p. 145. 
in refugee law first. ${ }^{63}$ This is necessary because refugee law is not part of the mandatory curriculum at law school / university.

This training usually takes approximately one or two semesters. Only after this training students have the knowledge and understanding of refugee law in order to be able to join meetings with refugees to provide legal advice. Afterwards the students will usually receive a certificate which confirms their acquired skills and knowledge.

\section{Legal advice from students}

Usually refugee law clinics have an open meeting once or twice per week to establish the first contact with refugees. Afterwards the refugee law clinic will work with the asylum seeker until a decision was made and either asylum or no asylum has been granted. The concept of immediate legal advice without an ongoing relation [so-called: ad hoc advice $]^{64}$ is not applicable here.

But a refugee law clinic does not only deal with refugee law. Also in other areas like civil law refugee law clinics try to help their clients. Sometimes the refugees are seeking for advice concerning everyday life which might be different from how it used to be in their countries of origin. But also, medical or psychological help is needed. Moreover, the refugee law clinic is helping to organise and prepare all meetings with

\footnotetext{
${ }^{63}$ See also Hilb, GJLE 2014, p. 123.
}

${ }^{64}$ See Hannemann, GJLE 2015, p. 141. 
the administration, preparing letters, helping to fill out forms as well as preparing the hearing of the refugee. ${ }^{65}$

If the refugee law clinic is not able to help on a particular problem it may send the refugee to a helping institution which is more familiar with the particular problem.

In Germany refugee law clinics cooperate with catholic and protestant church institutions (Caritas, Diakonie) as well as welfare institutions and social initiatives.

\section{The board of advisors}

There might come up situations in which students are not able to deal with a case anymore and the fully trained lawyer is necessary to help further. Students are trained to understand, whether the case requires professional help from a lawyer or not. If there are any doubts they have to consult their advising lawyer. This is what the German law provides with "guidance". Therefore, it is helpful to establish an advisory board consisting of lawyers / law professors / attorneys / notary publics etc. in order to fulfil the legal requirements of the "Rechtsdienstleistungsgesetz" concerning guidance / supervision. The members of the advisory board take the responsibility of guiding and supervising the practicing law students.

To build up an advisory board is not a problem for legal clinics. Most of lawyers are open-minded to this idea and feel honoured to work in a pro-bono-initiative. The idea of pro bono work of attorneys in Germany is older than law clinics and respected by

${ }^{65}$ See Oehl, BRJ [Bonner Rechtsjournal] 02/2013, p. 152. 
all lawyers. Actually, many lawyers already work on pro bono projects (e.g. giving legal advice to a charity club for free). But not only lawyers are advising refugee law clinics. Also, interpreters, translators and experts who are familiar with the appropriate cultures and nations are more than welcome to support the work of the refugee law clinic.

\section{Limitation of liability}

Since refugee law clinics mostly cannot afford a liability insurance, the limitation of liability of the law clinic is a point to be considered. The law clinic does not get any financial return for the legal advice. Neither the refugee can verify whether the legal advice from the law clinic is right. This indicates how important it is to deliver sustainable and well researched advice.

The best measure to limit liability is good organisation of the clinic and good monitoring of acting students. Nevertheless, one should also consider legal measures to limit liability.

The different mechanisms of limited liability protect the practicing students as well as the advisory board.

First of all the legal form of the refugee law clinic can already provide protection to a certain extent, if it is a legal form (corporate) that reduces liability for the advisor. Without choosing a specific legal form the law clinic will - under German law - be considered as society / association with unlimited liability (,Gesellschaft bürgerlichen 
Rechts"). ${ }^{66}$ In that case the legal advisor (student) will be fully liable on his own. If the law clinic provides wrong legal advice, the law student will have to pay the damage on his own. That is why most of the legal clinics in Germany chose corporate legal forms with limited liability, primarily a registered association ("eingetragener Verein"), which is a non-profit legal person with limited liability of its members. Most of refugee law clinics chose this legal form. ${ }^{67}$

Besides the legal form there are other ways to protect the law students from legal liability. It is possible to make a contract with the client, that specifies the danger of law students giving legal advice. In this contract liability can be limited to intent and gross negligence.

Another additional way to protect the students who work at the legal clinic is to take out insurance with an insurance company for all cases the law clinic is working on. According to $\S 51$ IV 1 Bundesrechtsanwaltsordnung (Federal law concerning attorneys) attorneys always have to be insured for at least $€ 250,000$ in each case. ${ }^{68}$ Possibly, liability problems could also be solved through the insurance of the supervising lawyers.

\footnotetext{
${ }^{66}$ See J.-G. A. Hannemann / G. Dietlein, StUdentische ReCHTSBERATUNG Und CliniCAL LeGAL EDUCATION IN DEUTSCHLAND 56 seq. (Springer Berlin 2016). no. 18 (Beck München 2014, 4th edition); differently: Hanns Prütting, Gutachten für den 65. Deutschen Juristentag 2004, p. G 48; Volker Römermann, NJW [Neue Juristische Wochenschrift] 2006, p. 3030.
} 


\section{Conclusion}

The field of refugee law clinics developed tremendously in Germany within the last few years. Nowadays one can find in almost every university city a law clinic and in most of them a refugee law clinic as well. Germany is a country of immigration. This is one of the reasons, why Germany is one of the economically strongest countries in Europe. Nevertheless, the refugee crisis from 2015 had a major impact on the country. Right wing parties became stronger and for the very first time a right-wing party (AfD) has entered German Parliament due to the parliamentary elections in September 2017. The fact that this party received $12.6 \%$ of the votes shows that the refugee crisis is affecting and worrying many people.

"When you come out of the storm you won't be the same person that walked in. That's what the storm is all about" (Haruki Murakami). 